\title{
アルカリ溶解性会合高分子溶液中を上昇する気泡に作用する特異な弾性効果
}

\section{Peculiar Elastic Effects on a Bubble Rising in Hydrophobically Modified Alkali-Soluble Associative Polymer Solutions}

\author{
○学 徳井紀彦（徳島大） 正 太田光浩（徳島大） \\ 正岩田修一（名エ大）
}

Norihiko TOKUI, The University of Tokushima, 2-1 Minamijyousanjima-cho, Tokushima 770-8506 Mitsuhiro OHTA, The University of Tokushima, 2-1 Minamijyousanjima-cho, Tokushima 770-8506 Shuichi IWATA, Nagoya Institute of Technology, Gokiso-cho, Showa-ku, Nagoya 466-8555

The motion of single bubbles rising in hydrophobically modified alkali-soluble associative (HASE) polymer solutions are experimentally examined. The non-Newtonian liquid is made up of 1.1 and $1.4 \mathrm{wt} \%$ HASE polymer solution, which are adjusted to $\mathrm{pH} \approx 7.0$ by adding a sodium hydroxide solution. Rising bubbles with threadlike shapes are observed, regardless of small Deborah number conditions. It is shown that unique shapes of the bubble largely depend on the HASE solution and the bubble size. Consideration for unique shapes is made based on enlarged pictures taken with a high-speed video camera.

Key Words: Bubble rise motion, Viscoelastic fluid, HASE solution

\section{1. 緒言}

工業的に使用されているア加溶解性会合高分子(HASE)溶 液中を上昇する気泡は, 非常にュニークな気泡形状で運動するこ とが Soto ら ${ }^{(1)}$ により初めて報告された。著者らは, Soto ら ${ }^{(1)}$ の研究条件より広範囲の物性・物理条件下で HASE 水溶液中 での気泡上昇運動を調べ, 特異な形状を有する気泡を観察し てきた ${ }^{(2-4)}$ 。これらの研究で観察される気泡は，古くから多 数の研究者により調べられてきた水溶性会合高分子溶液中 を上昇する気泡運動 ${ }^{(5-7)}$ とは全く異なり，気泡に作用する HASE 水溶液の特異な弾性効果に起因すると考えられる。し かし, HASE 水溶液の見掛けのレ加ジ一特性は水溶性高分子溶 液と同様の特性を有しており, この点が現象の考察を難しく する. 本研究では, 先の研究とは異なった条件で実験を行い, 特徵的な気泡形状の出現について議論するとともに，特徵的 な気泡形状部に焦点をあてて考察を行う。

\section{2. 実験方法}

Fig. 1 に実験装置を示す，装置本体は，正方断面形状 (0.25 $\mathrm{m} \times 0.25 \mathrm{~m}$ ) のアクリル塔 (高さ $1.1 \mathrm{~m}$ ) である. HASE として Primal TT-935(Rohm and Haas Co.)を用いた。 本研究では, $\mathrm{NaOH}$ を添加し, $\mathrm{pH} \approx 7$ に調整した $1.1 \mathrm{wt} \%$ よび $1.4 \mathrm{wt} \%$ HASE 水溶液を用いて実験を行った。実験では, 装置内を HASE 水溶液で満たし, 所定体積の気泡を装置下部に取り付 けた半球状のカップに貯めた後に単一気泡を放出した. 気泡運 動をビデオ・カxラ(500 fps) で撮影し，撮影映像から上昇速度を 算出した。実験で用いた流体物性は実測した。なお，実験で の水溶液温度 $20 \pm 1{ }^{\circ} \mathrm{C}$ であった。

Fig. 2 にHASE 水溶液の粘度 $(\eta)$ および第 1 法線応力差 $\left(\mathrm{N}_{1}\right)$ の剪断速度 $(\dot{\gamma})$ 依存性を示す. 図中の実線は, Carreau-Y asuda モデル(8)によるモデル・ライイである。本実験で用いた HASE 水溶 液は, Shear-thinning 性と弾性特性を有した非ニュート流体であ り,ゼ谫断速度粘度 $\left(\eta_{0}\right)$ は $1.1 \mathrm{wt} \% \mathrm{HASE}$ 水溶液で $\eta_{0}=0.13$ Pa.s, 1.4 wt $\%$ HASE 水溶液で $\eta_{0}=0.48$ Pa.s であった. L eider とBird の方法 ${ }^{(9)}$ より算出した緩和時間 $(\lambda)$ は, 両水溶液とも おおよそ $\lambda=0.005 \mathrm{~s}$ となった. $\eta_{0}$ で定義した M orton (M)数 条件は, $1.1 \mathrm{wt} \% \mathrm{HASE}$ 水溶液で $\mathrm{M}\left(=\mathrm{g}\left(\rho_{\mathrm{L}}-\rho_{\mathrm{G}}\right) \eta_{0}{ }^{4} / \rho_{\mathrm{L}}{ }^{2} \sigma^{3}\right)=$ $0.04,1.4$ wt $\%$ HASE 水溶液で $M=7.9$ である. ここで, $g$ : 重力加速度, $\rho_{\mathrm{L}}$ : 液相密度, $\rho_{\mathrm{G}}$ : 気相密度, $\sigma$ : 表面張力 で ある。

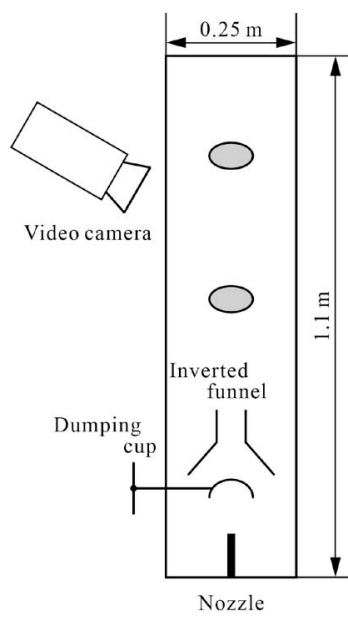

Fig. 1 Experimental system.

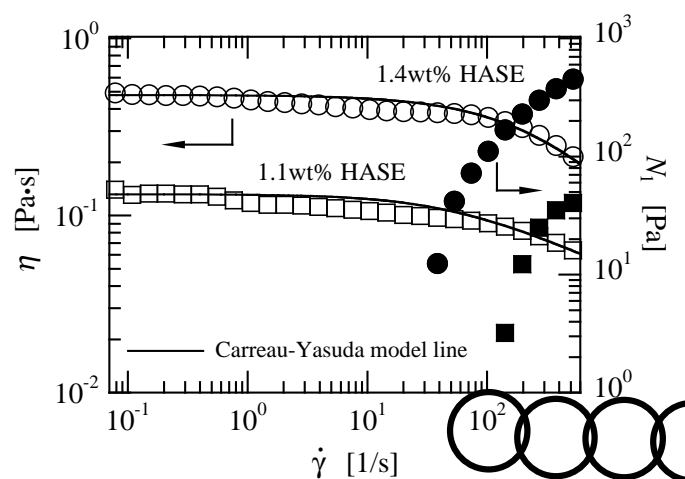

Fig. 2 Shear viscosity and first normal stress difference as a function of the shear rate.

\section{3. 結果と考察}

Figs. 3 と 4 にE ötvös 数 $\left(=g\left(\rho_{\mathrm{L}}-\rho_{\mathrm{G}}\right) \mathrm{d}^{2} / \sigma\right.$, d: 球体積相当径 $)$ に依存した気泡形状を示す. Fig. 3 は 1.1 wt\% HASE 水溶液 $(M=0.04)$ の場合, Fig. 4 は 1.4 wt $\%$ HASE 水溶液 $(M=7.9)$ の場合である.まず, 1.1 wt \% HASE 水溶液中の気泡 (Fig. 3) 


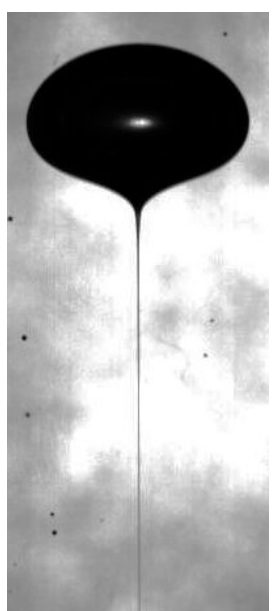

$E o=26$

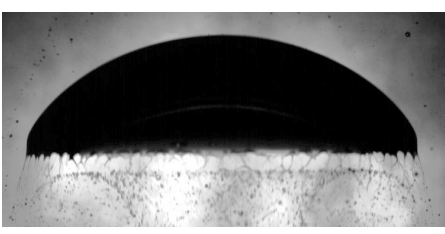

Overall view

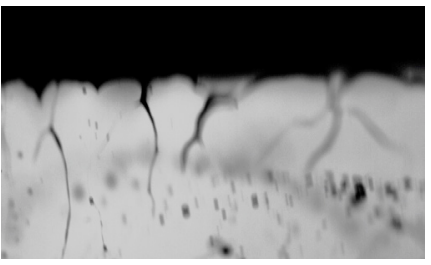

Enlarged view of the bottom

$$
E O=170
$$

Fig. 3 Experimental results for $M=0.04$.

Table 1 Experimental results for $R e$ and $D e$ numbers.

\begin{tabular}{ccccc}
\hline & E0 & & Re & De \\
\hline \hline \multirow{2}{*}{$M=0.04$} & 26 & 17.0 & 0.16 \\
\cline { 2 - 4 } & 170 & 70.6 & 0.10 \\
\hline \multirow{2}{*}{$M=7.9$} & 27 & 3.8 & 0.17 \\
\cline { 2 - 4 } & 175 & 18.3 & 0.12 \\
\hline
\end{tabular}

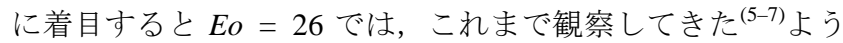
に気泡の底部に 1 本の非常に細長い系形状を形成寸る. 気泡 径が大きくなると $(E 0=170)$, 気泡形状は Cap 型になり, 気 泡形状底部の縁から無数の糸状部分が形成される. 拡大図か ら明らかな様に，この系形状はランダムに形成され，不規則に 枝分かれしている。枝形状の先端吹きでは, 気泡が細かく分 裂し，微細気泡が形成されているのが分かる.

$1.4 \mathrm{wt} \% \mathrm{HASE}$ 水溶液中の気泡 (Fig. 4) の場合, E0 = 27 で は, 1.4 wt\% HASE 水溶液の場合と同様に 1 本の非常に細長 い糸形状が形成されている. Fig. 4 には糸形状の先端部の拡 大写真も示したが, 先端部では微小気泡が連続的に繋がった ような形状を経て, 最終的に等間隔に比較的均一な又侈吹一个 の気泡が形成されていることが観察された. E0 = 175 の条件 の気泡は, 歪な気泡形状となっている. E0 数が 175 より大 きくなると, 劝一型気泡が形成されたため, E0 $=175$ の気泡 は, 劝一型気泡が形成される前段階 (過渡段階) にあると考え られる.この場合の特徵は, 気泡底部が非対称に歪な形で下 方に伸びていることである。この非対称な形状は, 気泡生成 時の流動条件に依存することが1つの可能性として考えられ， 今後の検討課題である. 気泡底部の拡大図を見ると, 気液界 面ではノギ形状が形成されているのが分かる。この/コギ师 状は，界面に沿って動いているように観察され，また時間と ともに気泡底部の歪な形状も不安定に変化した。

Table 1 に Reynolds $(\mathrm{Re})$ 数 $\left(=\rho_{\mathrm{L}} \mathrm{Vd} / \eta_{0}, \mathrm{~V}\right.$ : 気泡上昇速度) 之 Deborah $(\mathrm{De})$ 数 $(=2 \mathrm{~V} \lambda / \mathrm{d})$ の実験結果に示す. Table 1 の結果で 重要な点は, De 数の值が小さいことである. 見掛けの弾性 効果は非常に小さく, また見掛けの $\eta や \mathrm{~N}_{1}$ のレ加ジー特性も通 常の粘弹性流体の特性と变わらないにも関わらず, 特異な弹 性効果が発現する. HASE 水溶液系は, 劢ジー特性から現象 を予測し，制御できないことを示唆している.

\section{4. 結論}

本研究では, 先の研究とは異なった条件で実験を行い, 特

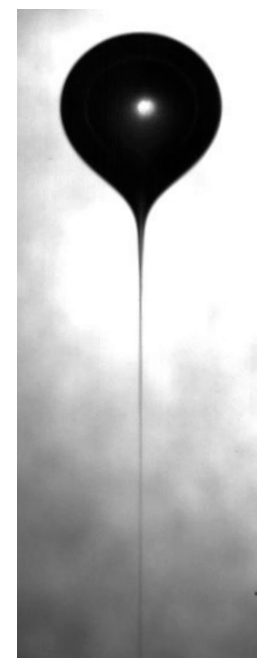

Overall view

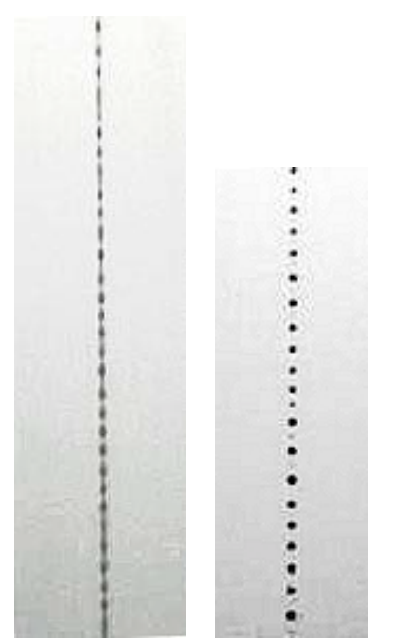

Enlarged views of leading end

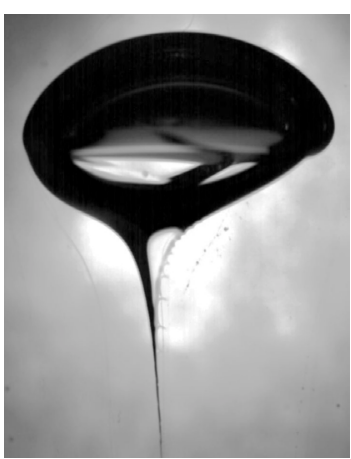

Overall view

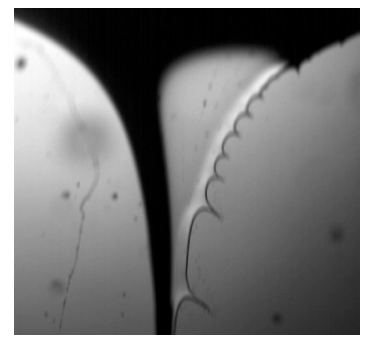

Enlarged view of tail

$$
E O=175
$$

Fig. 4 Experimental results for $M=7.9$.

徵的な気泡形状をより詳細に観察した。マ侈吹一ル・レベルで ダ什沙に変形する非常にユニークな気泡形状を観察した. HASE 水溶液が持つ特異な弹性応力効果の影響は, 溶液の濃度 (物 性值)や気泡径に依存して大きく異なることを確認した。

\section{謝辞}

本研究の一部は, (財) 高橋産業経済研究財団からの研究助 成ならびに日本学術振興会・科学研究費補助金 (基盤研究 (C) 24560180)より行われた。ここに感謝の意を表する.

\section{引用文献}

(1) E. Soto et al., Phys. F luids, 18, (2006) 121510.

（2）太田光浩ほか, 日本混相流学会年会講演会 2011 講演論 文集, (2011) 320-321.

(3) M. Ohta et al., Proc. 8th Int. Conf. M ultiphase Flow, (2013) ICM F 2013-972.

（4）太田光浩ほか，混相流シンポジウム 2013，(2013）F224.

(5) D. Rodrigue and D. De Kee, Rheol. Acta, 38, (1999) 177-182.

(6) R.G. Sousa, et al., J. Fluid M ech., 511 (2004) 217-236.

(7) S. A mirnia, et al., Chem. Eng. Sci., 94, (2013) 60-68.

(8) K. Y asuda et al., Rheol. Acta, 20, (1981) 163-178.

(9) P.J. Leider and R.B. Bird, Ind. Eng. Chem. Fundam., 13, (1974) 336-341. 